\title{
Efektivitas Ekstrak Buah Pare (Momordica charantia) dan Buncis (Phaseolus vulgaris) untuk Penurunan Kadar Gula Darah dan AUC (Area Under Curve) Tikus
}

\author{
Anisyah Achmad 1*, Dhea Novakinanda Regar ${ }^{2}$, Harwoko
}

${ }^{I}$ Program Studi Farmasi, Fakultas Kedokteran, Universitas Brawijaya Malang

${ }^{2}$ Program Studi Farmasi, Fakultas Ilmu Kesehatan, Universitas Jenderal Soedirman Purwokerto

INFO ARTIKEL

Sejarah artikel:

Penerimaan naskah: 25

Juli 2016

Penerimaan naskah

revisi: 26 Juli 2016

Disetujui untuk

dipublikasikan: 14

Desember 2016

\section{Kata kunci :}

AUC, Buncis, Kadar gula darah, Pare

\section{A B S T R A K}

Buah pare mengandung momordisin, momordin, asam resinat dan sterol, sedangkan buncis mengandung guava polyphenol. Kandungan senyawa tersebut dapat menurunkan kadar gula darah melalui stimulasi sekresi insulin. Tujuan penelitian ini untuk mengetahui efektivitas campuran buah pare dan buncis dalam menurunkan kadar gula darah dan area under curve. Penelitian dilakukan di Laboratorium Farmasi Klinik Universitas Jenderal Soedirman Purwokerto. Hewan uji dibagi menjadi 7 kelompok, terdiri atas 28 tikus. Kelompok 1 diberi metformin dalam NaCMC 1\% dengan dosis 9 mg/200 g BB tikus. Kelompok 2 diberi NaCMC $1 \%$ sebanyak 3 ml/200 g BB. Kelompok 3 ekstrak etanol buah pare $250 \mathrm{mg} / \mathrm{kg} \mathrm{BB}$. Kelompok 4 ekstrak etanol buah pare $125 \mathrm{mg} / \mathrm{kg}$ BB dan buncis $100 \mathrm{mg} / \mathrm{kg} \mathrm{BB}$. Kelompok 5 diberi $62,5 \mathrm{mg} / \mathrm{kg}$ BB dan $150 \mathrm{mg} / \mathrm{kg}$ BB. Kelompok 6 diberi $187,5 \mathrm{mg} / \mathrm{kg}$ BB dan $50 \mathrm{mg} / \mathrm{kg}$ BB. Kelompok 7 ekstrak etanol buah buncis $200 \mathrm{mg} / \mathrm{kg}$ BB. Setelah ekstrak, 30 menit kemudian diberi glukosa 1,35 g/200 g BB. Cuplikan darah diambil pada menit ke-0, 30, 60, 90, dan 120. Pengukuran kadar gula darah menggunakan metode electrochemical glucose biosensor. Berdasarkan analisis uji LSD, pemberian kombinasi ekstrak etanol buah pare dan buncis perbandingan 50\%:50\% menghasilkan interaksi sinergis dengan efek hipoglikemik yang berbeda signifikan dengan dibanding ekstrak etanol buah pare ataupun buncis secara tunggal. Simpulan dari penelitian ini ekstrak buah pare dan buncis 50\%:50\%, dapat menurunkan kadar gula darah dan area under curve tikus dengan efek sinergisme optimal.

\section{Effectiveness of Pare Fruit Extract (Momordica Charantia) and Beans (Phaseolus Vulgaris) for Lowering Blood Sugar Levels and AUC (Area Under Curve) in Rats}

\author{
Keywords: \\ children's diarrhea, \\ mother's level of \\ education, oralit, zinc
}

\begin{abstract}
A B S T R A C T
Diabetes mellitus is a degenerative disease that can cause a progressive decline in function and structure of body tissue. Pare fruits contain momordisin, momordin, resinat acids and sterols, whereas beans contain polyphenols. The compound can be used to lowering blood sugar levels by stimulating the insulin secretion. The aim of this study was to determine the effectiveness of mixing pare fruit and beans in lowering blood sugar levels and the area under curve. The study was conducted at the Laboratory of Clinical Pharmacy, Soedirman University Purwokerto. The test animals were randomly divided into seven groups, each groups consisted of 4 mice. Group 1 to 7 was given, respectively, metformin in NaCMC $1 \%$, $9 \mathrm{mg} / 200 \mathrm{~g} \mathrm{BB}$ rats; NaCMC $1 \% 3 \mathrm{ml} / 200 \mathrm{~g}$ body weight; ethanol extract of pare fruit $250 \mathrm{mg} / \mathrm{kg}$ $(100 \%)$; ethanol extract of $75 \%$ pare fruit $(187.5 \mathrm{mg} / \mathrm{kg})+25 \%$ beans $(50 \mathrm{mg} / \mathrm{kg})$; ethanol extract of $50 \%$ pare fruit $(125 \mathrm{mg} / \mathrm{kg})+50 \%$ beans $(100 \mathrm{mg} / \mathrm{kg})$; ethanol extract of $25 \%$ pare fruit $(62.5 \mathrm{mg} /$ $\mathrm{kg})+75 \%$ beans $(150 \mathrm{mg} / \mathrm{kg})$; and ethanol extract of beans $200 \mathrm{mg} / \mathrm{kg}(100 \%)$. Each group was given glucose $1.35 \mathrm{~g} / 200 \mathrm{~g}$ body weight 30 minutes after the extract administration. The daily food intake was 0.5 ounces and given three times daily. Blood was taken at minute $0,30,60,90$, and 120 . Blood sugar was measured by using a glucose electrochemical biosensors. The combined ethanol extract of pare fruit and beans with concentration of 50\%: 50\% produced a synergistic interaction and the most effective hypoglycemic effect. The conclusions of this study was ethanol extract of pare fruit and beans 50\%: $50 \%$ is potential in lowering blood sugar levels and the AUC in rats
\end{abstract}

* Corresponding author Anisyah Achmad, Program Studi Farmasi, Fakultas Kedokteran, Universitas Brawijaya, Jalan Veteran, Malang 65145, Jawa Timur, Indonesia Tel.: +62812-5563-6910; Fax:+62341-564755. E-mail: 3littleangels@ub.ac.id 


\section{Pendahuluan}

Penyakit diabetes melitus merupakan salah satu dari beberapa penyakit degeneratif, yaitu penyakit yang timbul akibat penurunan secara progesif fungsi atau struktur dari jaringan atau organ tubuh yang disebabkan oleh penambahan usia atau pilihan gaya hidup. Menurut laporan WHO, pada tahun 2000 lalu diperkirakan terdapat 4 juta penderita diabetes di Indonesia. Jumlah ini diperkirakan akan terus meningkat. Pada tahun 2010 diperkirakan menjadi 5 juta dan tahun 2030 diperkirakan sekitar 21,3 juta penduduk Indonesia menderita diabetes. ${ }^{1,2}$

Banyak tumbuhan di Indonesia yang terbukti digunakan sebagai salah satu sumber bahan baku antidiabetes melitus, karena tumbuhan tersebut mempunyai senyawa-senyawa yang berkhasiat menurunkan gula darah. Diantara 250.000 spesies tanaman obat di seluruh dunia diperkirakan banyak yang mengandung senyawa antidiabetes melitus yang belum diketemukan seperti buncis dan pare. ${ }^{3}$

Buah Buncis telah digunakan sebagai fitoterapi oleh sebagian masyarakat untuk menurunkan kadar gula darah penderita diabetes mellitus. ${ }^{4}$ Buncis mengandung guava polyphenol yang bersifat anti oksidan. Konsumsi buncis menurunkan kadar gula darah karena stimulasi sekresi insulin. Hal ini dapat dilihat dari meningkatnya kandungan insulin dalam darah setelah pemberian ekstrak buncis. Buah pare selain dikenal sebagai sayuran juga digunakan sebagai obat tradisional. Beberapa hasil penelitian menyimpulkan bahwa perasan buah pare dapat menurunkan kadar glukosa darah. Buah pare mengandung momordisin, momordin, asam resinat dan sterol ${ }^{5}$. Sementara itu, data ilmiah kombinasi penggunaan buah buncis dan pare terhadap penurunan kadar gula darah belum pernah ditemukan oleh peneliti.

Oleh karena itu, suatu penelitian tentang efektivitas campuran ekstrak buah pare dan buncis terhadap penurunan gula darah perlu dilakukan untuk mendapatkan data ilmiah yang dapat digunakan untuk keperluan klinis terutama untuk perkembangan keilmuan penyakit diabetes melitus.

\section{Metode}

Variabel dalam penelitian ini terdiri dari konsentrasi campuran ekstrak buah pare dan buncis serta efek penurunan kadar glukosa darah dan AUC.

Buah pare dan buncis yang diperoleh dari Desa Poncot, Kecamatan Kebasen, Kabupaten Banyumas. Pengambilan tanaman dilakukan di bawah sinar matahari (pukul 10.00 12.00 WIB), karena diperkirakan pada waktu tersebut fotosintesis tanaman berlangsung sempurna. Tanaman dibuat serbuk dengan dikeringkan dibawah sinar matahari dengan ditutup kain hitam. Sebanyak $500 \mathrm{~g}$ serbuk simplisia kering direndam dalam 2 liter etanol 96\% pada suhu kamar selama 24 jam, lalu disaring dengan kertas saring. Filtrat ditampung, ampas diulang hingga 3 kali kemudian dilakukan evaporasi.

Penetapan dosis metformin yang diberikan per oral sebesar $9 \mathrm{mg} / 200 \mathrm{~g}$ BB. Dosis glukosa per oral sebesar 1,35 $\mathrm{g} / 200 \mathrm{~g}$ BB (Lola et al., 2008). Sebelum perlakuan, hewan uji dipuasakan selama 12-18 jam dan diberi minum ad libitum. Semua kelompok tikus diberi ekstrak, 30 menit atau 60 menit (sesuai uji pendahuluan) kemudian diinduksi glukosa dosis $1,35 \mathrm{~g} / 200 \mathrm{~g}$ BB.

Hewan uji dibagi secara acak menjadi 7 kelompok dan masing-masing terdiri atas 4 tikus. Kelompok 1 (metformin dalam NaCMC $1 \%$ dengan dosis $9 \mathrm{mg} / 200 \mathrm{~g}$ BB tikus. Kelompok 2 diberi NaCMC $1 \%$ sebanyak $3 \mathrm{ml} / 200 \mathrm{~g}$ BB. Kelompok 3 diberi ekstrak etanol buah pare $250 \mathrm{mg} / \mathrm{kg}$ BB. Kelompok 4 diberi kombinasi ekstrak etanol buah pare 125 $\mathrm{mg} / \mathrm{kg}$ BB dan buah buncis $100 \mathrm{mg} / \mathrm{kg}$ BB. Kelompok 5 kombinasi ekstrak etanol buah pare $62,5 \mathrm{mg} / \mathrm{kg}$ BB dan buah buncis $150 \mathrm{mg} / \mathrm{kg}$ BB. Kelompok 6 kombinasi ekstrak etanol buah pare $187,5 \mathrm{mg} / \mathrm{kg} \mathrm{BB}$ dan buah buncis $50 \mathrm{mg} / \mathrm{kg}$ BB. Kelompok 7 diberi ekstrak etanol buah buncis 200 $\mathrm{mg} / \mathrm{kg}$ BB. Setelah diberi ekstrak, 30 menit kemudian diberi glukosa 1,35 g/200 g BB. Semua perlakukan secara per oral. Cuplikan darah diambil dari vena lateralis ekor pada menit ke-0, 30, 60, 90, dan 120 yang dihitung setelah pemberian glukosa kemudian diukur dengan menggunakan metode electrochemical glucose biosensor.

\section{Hasil}

Pada preparasi ekstrak buah pare dan buncis didapatkan ekstrak kental sebanyak $30 \mathrm{~g}$ dengan rendemen yang dihasilkan sebesar 6\%. Ekstrak etanol buah pare dan buncis diuji organoleptik dengan menggunakan panca indera untuk mendeskripsikan warna, rasa dan bau dari kedua ekstrak tersebut. Hasil uji organoleptik disajikan pada tabel 1 .

Tabel 1. Hasil Uji Organoleptik Ekstrak Etanol Buah Pare dan Buncis

\begin{tabular}{cccc}
\hline Ekstrak & Warna & Rasa & Bau \\
\hline Pare & Coklat tua & Pahit & Khas aromatik \\
Buncis & Hijau tua & Tidak pahit & Khas aromatik \\
\hline
\end{tabular}

Hasil uji pendahuluan penetapan waktu pemberian glukosa diperoleh data $\mathrm{AUC}_{0-120}$ Data $\mathrm{AUC}_{0-120}$ menunjukkan waktu paling efektif adalah pada selang waktu 30 menit setelah pemberian sediaan uji. Hal ini dibuktikan dengan nilai $\mathrm{AUC}_{0-120}$ yang lebih kecil yaitu 14.880 menit $\mathrm{mg} / \mathrm{dL}$ dibandingkan dengan selang waktu 60 menit setelah pemberian sediaan uji seperti terlihat pada Tabel 2.

Uji efek hipoglikemik menggunakan metode uji toleransi glukosa yaitu menginduksi glukosa pada hewan uji untuk membuat kondisi hiperglikemik. Data kadar glukosa darah yang diperoleh dapat dilihat pada Tabel 3 . 
Kadar glukosa darah pada penelitian ini dibuat kurva hubungan antara kadar glukosa darah $(\mathrm{mg} / \mathrm{dL})$ per satuan waktu pengamatan (menit) yang dapat dilihat pada Gambar 1 .

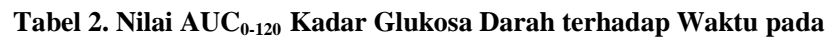
Uji Pendahuluan Waktu Pemberian Glukosa

\begin{tabular}{ccc}
\hline \multirow{2}{*}{ Tikus } & \multicolumn{2}{c}{ AUC $_{\mathbf{0 - 1 2 0}}$ (menit mg/dL) } \\
\cline { 2 - 3 } & Kelompok 1 & Kelompok 2 \\
\hline 1 & 16605 & 14640 \\
2 & 16155 & 15075 \\
3 & 19455 & 14925 \\
\hline Rata-rata & 17405 & 14880 \\
\hline
\end{tabular}

Keterangan:

Kelompok 1: Hewan uji diinduksi glukosa 30 menit setelah pemberian sediaan uji.

Kelompok 2: Hewan uji diinduksi glukosa 60 menit setelah pemberian sediaan uji.

Tabel 3. Rata-rata Kadar Glukosa Darah Tikus (mg/dl) pada Tiap Kelompok Kontrol dan Perlakuan

\begin{tabular}{cccccc} 
K & \multicolumn{5}{c}{ Rata-rata Kadar Glukosa Darah (mg/dL) Pada } \\
& \multicolumn{5}{c}{ menit ke- } \\
\cline { 2 - 6 } & 0 & 30 & 60 & 90 & 120 \\
\hline K1 & 111 & 110,75 & 129,25 & 128,5 & 95 \\
K2 & 108,75 & 195,25 & 193,75 & 173,75 & 124,75 \\
K3 & 127,75 & 134 & 140,5 & 131,75 & 111 \\
K4 & 110,75 & 129 & 143,75 & 141,75 & 107,5 \\
K5 & 116,25 & 121 & 128 & 118,75 & 99,25 \\
K6 & 123,75 & 129,5 & 129,75 & 138,5 & 113,75 \\
K7 & 116,25 & 134,75 & 138 & 130,5 & 120,5 \\
\hline
\end{tabular}

Keterangan:

$\mathrm{K}:$ Kelompok

K1: Kontrol positif dengan perlakuan metformin $9 \mathrm{mg} / 200 \mathrm{~g} \mathrm{BB}$

K2: Kontrol negatif dengan perlakuan NaCMC $1 \%$

K3: Perlakuan dengan ekstrak etanol buah pare konsentrasi 100\% (250 $\mathrm{mg} / \mathrm{kg} \mathrm{BB}$ )

K4: Perlakuan dengan kombinasi ekstrak etanol buah pare konsentrasi $75 \%(187,5 \mathrm{mg} / \mathrm{kg} \mathrm{BB})$ dan buncis konsentrasi $25 \%$ (50 mg/kg BB)

K5: Perlakuan dengan kombinasi ekstrak etanol buah pare konsentrasi $50 \%(125 \mathrm{mg} / \mathrm{kg} \mathrm{BB})$ dan buncis konsentrasi $50 \%$ (100 mg/kg BB)

K6: Perlakuan dengan kombinasi ekstrak etanol buah pare konsentrasi $25 \%(62,5 \mathrm{mg} / \mathrm{kg} \mathrm{BB})$ dan buncis konsentrasi $75 \%(150 \mathrm{mg} / \mathrm{kg} \mathrm{BB})$

K7: Perlakuan dengan ekstrak etanol buah buncis konsentrasi 100\% (200 $\mathrm{mg} / \mathrm{kg} \mathrm{BB}$ )

$\mathrm{AUC}_{0-120}$ digunakan sebagai gambaran efek hipoglikemik dari kombinasi ekstrak etanol buah pare dan buah buncis. Semakin kecil nilai $\mathrm{AUC}_{0-120}$ maka efek hipoglikemik semakin besar. Data $\mathrm{AUC}_{0-120}$ dapat dilihat pada Tabel 4.

Data $\mathrm{AUC}_{0-120}$ yang diperoleh dianalisis secara statistik dengan metode statistik parametrik yaitu uji Anova Satu Arah. Hasil analisis data menunjukkan nilai F hitung sebesar 32,464. Hal ini menunjukkan terdapat perbedaan yang bermakna antar kelompok karena $\mathrm{F}$ hitung lebih besar dari $\mathrm{F}$ tabel (2,57). Selanjutnya data dianalisis dengan uji Least Significant Difference (LSD) untuk mengetahui perbedaan antar kelompok (Tabel 5).

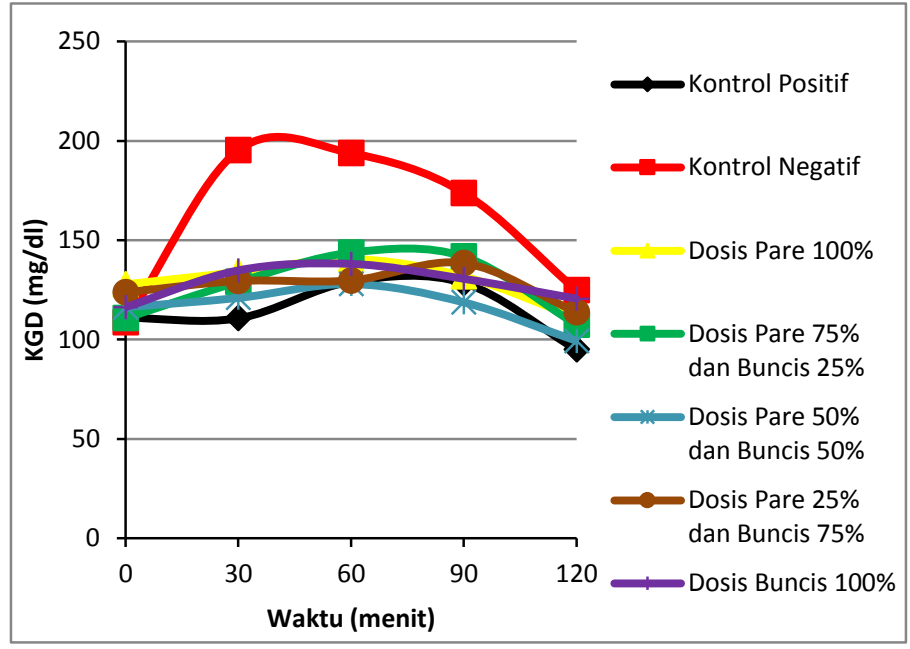

Gambar 1. Kurva Hubungan Rata-rata Kadar Glukosa Darah (mg/dl) terhadap Waktu (menit) pada Tiap Kelompok

Tabel 4. Rata-rata Area Under Curve dari menit 0-120' $\left(\mathrm{AUC}_{0-120}\right)$ untuk Tiap Kelompok

\begin{tabular}{|c|c|c|}
\hline No & Kelompok & $\begin{array}{c}\text { Rata- } \\
\text { rata AUC } \\
\text { (menit } \\
\text { mg/dL) }\end{array}$ \\
\hline 1. & Kontrol positif perlakuan metformin $9 \mathrm{mg} / \mathrm{kg} \mathrm{BB}$ & $14.171,25$ \\
\hline 2. & Kontrol negatif perlakuan $\mathrm{NaCMC} 1 \%$ & $20.385,00$ \\
\hline 3. & $\begin{array}{l}\text { Perlakuan ekstrak etanol buah pare konsentrasi } \\
100 \%(250 \mathrm{mg} / \mathrm{kg} \mathrm{BB})\end{array}$ & $15.768,75$ \\
\hline 4. & $\begin{array}{l}\text { Perlakuan kombinasi ekstrak etanol buah pare } \\
\text { konsentrasi } 75 \%(187,5 \mathrm{mg} / \mathrm{kg} \mathrm{BB}) \text { dan buncis } \\
\text { konsentrasi } 25 \%(50 \mathrm{mg} / \mathrm{kg} \mathrm{BB})\end{array}$ & $15.635,75$ \\
\hline 5. & $\begin{array}{l}\text { Perlakuan kombinasi ekstrak etanol buah pare } \\
\text { konsentrasi } 50 \%(125 \mathrm{mg} / \mathrm{kg} \mathrm{BB}) \text { dan buncis } \\
\text { konsentrasi } 50 \%(100 \mathrm{mg} / \mathrm{kg} \mathrm{BB})\end{array}$ & $14.265,00$ \\
\hline 6. & $\begin{array}{l}\text { Perlakuan kombinasi ekstrak etanol buah pare } \\
\text { konsentrasi } 25 \%(62,5 \mathrm{mg} / \mathrm{kg} \mathrm{BB}) \text { dan buncis } \\
\text { konsentrasi } 75 \%(150 \mathrm{mg} / \mathrm{kg} \mathrm{BB})\end{array}$ & $15.427,50$ \\
\hline 7. & $\begin{array}{l}\text { Perlakuan ekstrak etanol buah buncis konsentrasi } \\
100 \%(200 \mathrm{mg} / \mathrm{kg} \mathrm{BB})\end{array}$ & $15.648,75$ \\
\hline
\end{tabular}

\section{Pembahasan}

Rasa pahit hasil uji organoleptik pada ekstrak etanol buah pare dipengaruhi oleh kandungan momordikosida 
(triterpenoid kukurbitasin) yaitu momordikosida $\mathrm{K}$ $\left(\mathrm{C}_{37} \mathrm{H}_{58} \mathrm{O}_{9}\right)$ dan momordikosida $\mathrm{L}\left(\mathrm{C}_{36} \mathrm{H}_{58} \mathrm{O}_{9}\right) .{ }^{6,7,8}$

Pada kelompok 2 sudah mulai meningkatkan kadar glukosa darah dan sediaan uji telah mengalami absorbsi sehingga glukosa darah tikus dapat menjadi normal kembali dengan adanya pengaruh ekstrak tersebut, sedangkan pada kelompok 1 menunjukkan data $\mathrm{AUC}_{0-120}$ yang lebih besar, karena kemungkinan glukosa masuk ke dalam tubuh tikus pada saat ekstrak sudah tereliminasi, sehingga efek menurunkan gukosa darah tidak maksimal dan glukosa darah tikus tetap tinggi. Data kadar glukosa darah tikus yang diperoleh dibandingkan dengan kadar glukosa darah normal tikus yang berkisar 50-135 mg/dl. Pada kelompok 2 (kontrol negatif) terjadi kondisi hiperglikemik yang ditandai dengan kadar glukosa darah tikus di atas normal yaitu $>135 \mathrm{mg} / \mathrm{dl}$. Pada kelompok 1 (kontrol positif) yang diberi metformin menunjukkan kadar glukosa yang lebih rendah dibandingkan dengan kontrol negatif, ini menunjukkan bahwa metformin mempunyai efek hipoglikemik.

Tabel 5. Perbandingan Data Rata-rata $\mathrm{AUC}_{0-120}$, Anova, dan LSD Kelompok 5 dengan Kelompok Lain

\begin{tabular}{|c|c|c|c|}
\hline $\mathbf{K}$ & $\begin{array}{c}\text { Rata-rata } \\
\text { AUC }_{0-120} \\
(\text { menit } \\
\text { mg/dL) }\end{array}$ & Anova & $\begin{array}{c}\text { LSD } \\
\text { K5 vs K- }\end{array}$ \\
\hline $\mathrm{K} 1$ & $14.171,25$ & $\begin{array}{c}\text { Ada perbedaan } \\
\text { bermakna }\end{array}$ & $\begin{array}{c}\text { Tidak berbeda } \\
\text { bermakna }\end{array}$ \\
\hline $\mathrm{K} 2$ & 20.385 & $\begin{array}{c}\text { Ada perbedaan } \\
\text { bermakna }\end{array}$ & Berbeda bermakna \\
\hline K3 & $15.768,75$ & $\begin{array}{c}\text { Ada perbedaan } \\
\text { bermakna }\end{array}$ & Berbeda bermakna \\
\hline K4 & $15.635,75$ & $\begin{array}{c}\text { Ada perbedaan } \\
\text { bermakna }\end{array}$ & Berbeda bermakna \\
\hline K5 & 14.265 & - & - \\
\hline K6 & $15.427,5$ & $\begin{array}{c}\text { Ada perbedaan } \\
\text { bermakna }\end{array}$ & Berbeda bermakna \\
\hline K7 & $15.648,75$ & $\begin{array}{c}\text { Ada perbedaan } \\
\text { bermakna }\end{array}$ & Berbeda bermakna \\
\hline
\end{tabular}

Keterangan:

K: Kelompok

K1: Kontrol positif dengan perlakuan metformin $9 \mathrm{mg} / 200 \mathrm{~g} \mathrm{BB}$

K2: Kontrol negatif dengan perlakuan NaCMC $1 \%$

K3: Perlakuan dengan ekstrak etanol buah pare konsentrasi 100\% (250 $\mathrm{mg} / \mathrm{kg} \mathrm{BB}$ )

K4: Perlakuan dengan kombinasi ekstrak etanol buah pare konsentrasi 75\% $(187,5 \mathrm{mg} / \mathrm{kg} \mathrm{BB})$ dan buncis konsentrasi $25 \%$ (50 mg/kg BB)

K5: Perlakuan dengan kombinasi ekstrak etanol buah pare konsentrasi 50\% (125 mg/kg BB) dan buncis konsentrasi 50\% (100 mg/kg BB)

K6: Perlakuan dengan kombinasi ekstrak etanol buah pare konsentrasi $25 \%$ $(62,5 \mathrm{mg} / \mathrm{kg} \mathrm{BB})$ dan buncis konsentrasi $75 \%(150 \mathrm{mg} / \mathrm{kg} \mathrm{BB})$

K7: Perlakuan dengan ekstrak etanol buah buncis konsentrasi 100\% (200 $\mathrm{mg} / \mathrm{kg} \mathrm{BB}$ ) $\mathrm{AUC}_{0-120}$ : Area Under Curve menit 0-120

LSD: Least Significant Difference
Berdasarkan Gambar 1, kelompok kontrol positif dan kelompok perlakuan memiliki efek hipoglikemik jika dibandingkan dengan kelompok kontrol negatif yang kadar glukosa darahnya lebih tinggi dibandingkan dengan kelompok lain. Selanjutnya dihitung Area Under Curve (AUC) dari menit 0-120 (AUC $\left.\mathrm{Al}_{0-120}\right)$ dengan menggunakan rumus:

$$
\left[A U C_{t_{n-1}}^{t_{n}}\right]=\frac{C_{n-1}+C_{n}}{2}\left(t_{n}-t_{n-1}\right)
$$

Keterangan : $t_{n}$ : waktu pengamatan dari konsentrasi obat $C_{n}$

$\mathrm{t}_{\mathrm{n}-1}$ : waktu pengamatan sebelumnya yang berhubungan dengan konsentrasi obat $\mathrm{C}_{\mathrm{n}-1}$.

Berdasarkan analisis data uji LSD terlihat bahwa kelompok 1, 3, 4, 5, 6 dan 7 berbeda bermakna dengan kelompok 2. Hal ini menunjukkan bahwa kelompok kontrol positif dan seluruh kelompok perlakuan memiliki efek hipoglikemik. Kelompok 3 (perlakuan dengan ekstrak etanol buah pare $100 \%$ ) memiliki efek hipoglikemik yang ditandai dengan $\mathrm{AUC}_{0-120}$ yang lebih kecil dibandingkan $\mathrm{AUC}_{0-120}$ kelompok 2 (kontrol negatif), hal ini didukung penelitian Lola et al., (2008) bahwa ekstrak etanol buah pare pada konsentrasi $250 \mathrm{mg} / \mathrm{kg}$ BB memiliki efek hipoglikemik yang sama dengan glibenklamid pada tikus putih diabetik. Demikian juga kelompok 7 (perlakuan dengan ekstrak etanol buah buncis 100\%) memiliki efek hipoglikemik yang ditandai dengan $\mathrm{AUC}_{0-120}$ yang lebih kecil dibandingkan $\mathrm{AUC}_{0-120}$ kelompok 2 (kontrol negatif), hal ini didukung penelitian Venkateswaran dan Pari (2002) bahwa ekstrak etanol buah buncis pada konsentrasi $200 \mathrm{mg} / \mathrm{kg}$ BB memiliki efek hipoglikemik yang sama dengan glibenklamid pada tikus putih diabetik.

Kelompok 3, 4, 6 dan 7 masing-masing jika dipasangkan menunjukkan hasil tidak berbeda bermakna, hal ini menunjukkan bahwa semua kelompok tersebut yaitu kelompok perlakuan dengan ekstrak etanol buah pare konsentrasi $100 \%(250 \mathrm{mg} / \mathrm{kg} \mathrm{BB})$, perlakuan dengan kombinasi ekstrak etanol buah pare konsentrasi $75 \%(187,5$ $\mathrm{mg} / \mathrm{kg} \mathrm{BB})$ dan buah buncis konsentrasi $25 \%(50 \mathrm{mg} / \mathrm{kg}$ $\mathrm{BB})$, perlakuan dengan kombinasi ekstrak etanol buah pare konsentrasi $25 \% \quad(62,5 \mathrm{mg} / \mathrm{kg} \mathrm{BB})$ dan buah buncis konsentrasi $75 \%$ (150 mg/kg BB), perlakuan dengan ekstrak etanol buah buncis konsentrasi $100 \%(200 \mathrm{mg} / \mathrm{kg} \mathrm{BB}$ ) memilki efek hipoglikemik yang tidak berbeda bermakna.

Kelompok 3, 4, 6 dan 7 menunjukkan hasil berbeda bermakna dengan kelompok 1 . Hal ini menunjukkan bahwa kelompok tersebut memiliki efek hipoglikemik yang berbeda bermakna dengan kelompok kontrol positif metformin. Kelompok 5 dan 1 tidak berbeda bermakna, hal ini menunjukkan bahwa kelompok perlakuan dengan kombinasi ekstrak etanol buah pare konsentrasi 50\% (125 $\mathrm{mg} / \mathrm{kg} \mathrm{BB}$ ) dan buncis konsentrasi 50\% (100 mg/kg BB) memiliki efek hipoglikemik yang tidak berbeda bermakna dengan kelompok kontrol positif metformin.

Berdasarkan analisis data uji LSD menunjukkan 
bahwa perlakuan dengan kombinasi ekstrak etanol buah pare konsentrasi $50 \% \quad(125 \mathrm{mg} / \mathrm{kg} \quad \mathrm{BB})$ dan buncis konsentrasi $50 \% \quad(100 \mathrm{mg} / \mathrm{kg} \quad \mathrm{BB})$ menghasilkan efek hipoglikemik paling baik jika dibandingkan dengan kelompok perlakuan lain $(\mathrm{p}<0,05)$ dan memiliki efek hipoglikemik yang tidak berbeda bermakna dengan kelompok kontrol positif metformin $(p>0,05)$. Hal ini juga menunjukkan bahwa efek sinergis dari kombinasi buah pare dan buncis terbukti meningkatkan efek hipoglikemik dengan perbandingan konsentrasi 50\% ekstrak etanol buah pare (125 mg/kg BB) dan konsentrasi 50\% ekstrak etanol buah buncis $(100 \mathrm{mg} / \mathrm{kg} \mathrm{BB})$.

Campuran alami yang ditemukan dalam suatu ekstrak tumbuhan dapat memberikan keuntungan yang berasal dari interaksi antar komponen-komponen yang dikandungnya. ${ }^{10}$ Kombinasi produk obat herbal dan ekstrak herbal dapat menghasilkan interaksi zero, positif (sinergis) dan negatif (antagonis). Interaksi positif merupakan interaksi yang diharapkan dalam pengembangan produk herbal kombinasi. Perbedaan konsentrasi kombinasi dari obat dengan efek yang sama dapat menunjukkan perbedaan interaksi. ${ }^{11}$ Pengertian sinergis di sini mengacu pada efek yang dihasilkan dari suatu komponen produk. Suatu kombinasi produk obat herbal atau ekstrak herbal dikatakan sinergis jika menghasilkan efek yang lebih besar dibandingkan efek masing-masing komponen tunggalnya. ${ }^{12}$ Pada penelitian ini pemberian kombinasi ekstrak etanol buah pare dan buncis dengan perbandingan konsentrasi 75\%:25\% dan 25\%:75\% menghasilkan interaksi zero karena menghasikan efek hipoglikemik yang tidak berbeda signifikan dengan pemberian ekstrak etanol buah pare ataupun buncis secara tunggal. Pemberian kombinasi ekstrak etanol buah pare dan buncis dengan perbandingan konsentrasi 50\%:50\% menghasilkan interaksi positif (sinergis) karena menghasikan efek hipoglikemik yang berbeda signifikan dengan pemberian ekstrak etanol buah pare ataupun buncis secara tunggal.

\section{Kesimpulan}

Campuran ekstrak buah pare (Momordica charantia) dan buncis (Phaseolus vulgaris) dapat menurunkan kadar gula darah tikus dengan efek sinergisme optimal dengan perbandingan konsentrasi 50\%:50\%.

\section{Daftar Pustaka}

1. Wild, S., Roglic, G., Geen, A. Global Prevalence of Diabetes. Estimates for the year 2000 and projections 2030. Diabetes Care. 2004; 27(5). Available from URL : http://care.diabetesjournals.org/content/27/5/1047. full. Accessed Mei 23, 2013.

2. Anonim. Berita aktual badan POM. Mengenal beberapa tanaman yang digunakan sebagai antidiabetika. 2005. Diangkat dari URL: http://www.pom.go.id/public/berita_aktual/detail. asp?id=74\&qs_menuid=2. Diakses Juli 18, 2013

3. Genatrika, E. Standarisasi Ekstrak Etanol Daun Teh (Camellia sinensis L) Sebagai Antidiabetik Pada Tikus Putih Galur Wistar. Skripsi. Fakultas Kedokteran dan Ilmu-ilmu Kesehatan Universitas Jenderal Soedirman. Purwokerto. Tidak dipublikasikan. 2009.

4. Muhlisah, F. Tanaman Obat Keluarga. PT. Penebar Swadaya. Jakarta. 2001.

5. Badan Pengawas Obat dan Makanan RI. Acuan Herbal Indonesia. Volume kelima. Edisi Pertama. 2010.

6. Subahar, T., dan Tim Lentera. Khasiat dan Manfaat Pare: Si Pahit Pembasmi Penyakit. Agomedia Pustaka. Jakarta. 2004.

7. Harinantenaina, L., Tanaka, M., dan Takaoka, S. Momordica charantia constituents and antidiabetic screening of the isolated major compounds, Chem Pharm Bull (Tokyo). 2006;54:1017-1021. Available from URL :http://www.ncbi.nlm.nih.gov/pubmed/16819222. Accessed Juli 19, 2013.

8. Tan, MJ., Ye, JM, Turner, N., Hohnen-Behrens, C., Ke CQ., Tang, CP., Chen, T., Weiss, HC., Gesing, ER., Rowland, A., James, DE., and Ye Y. Antidiabetic Activities of Triterpenoids Isolated from Bitter Melon Associated with Activation of the AMPK Pathway, Chemistry and Biology; 2008: 15, 253-273. Available from URL: http://www.sciencedirect.com/science/article/pii/S 1074552108000823. Accessed Juni 18, 2013.

9. Lola, MHC., Liben, P., dan Soemartojo, J. Efek Kombinasi Jus Daging Buah Pare (Momordica charantia L.) dan Jus Umbi Bawang Putih (Allium sativum L.) terhadap Penurunan Kadar Glukosa Darah, Jurnal Obat Bahan Alam; 2008: 7(1), 28-33.

10. Heinrich, M., Barners, J., Gibbons, S., dan Williamson, A.M. Farmakognosi dan Fitoterapi, diterjemahkan oleh Syarief, W.R., Aisyah, C., Elviana, E., dan Fidiasari, E.R, 179, EGC, Jakarta. 2008.

11. Suhnel, J. Evaluation of Synergism or Antagonism for The Combined Action of Ativiral Agents. Antiviral Research Elsevier, 13 (1990) 23-40. Available from : http://www2.leibnizfli.de/www_bioc/CombiTool/suehnel_ANTIVIRA L_RES_1990.pdf. Accessed Mei 23, 2013.

12. Houghton, $P$ dan Mukherjee, PK. Evaluation of Herbal Medicinal Products. School of Natural Product Studies. Jadavpur University. Kolkota, India; 2007: 87-94. 